\title{
Effect of Benzoic and Sorbic Acids on Mycotoxins Inhibition in Edible Broad Bean Seeds
}

\author{
N. H.Youssef ${ }^{2}$, I. A. El samra ${ }^{1}$ and A. I. Abdel Bary ${ }^{1}$ \\ ${ }^{1}$ Department of Agricultural Botany, Faculty of Agriculture(Saba-Bacha), Alexandria \\ University, P. O. Box 21531, Bolkley, Alexandria, Egypt. ${ }^{2}$ Regional Centre for Food and \\ Feed, Alexandria, Agricultural Researches Centre, Egyptian Ministry of Agriculture, El - \\ Giza, Cairo, Egypt
}

Corresponding author: I. A. Elsamra, email: ibelsamra@hotmail.com

\begin{abstract}
Natural infected broad bean seeds were collected from Noubaria region during the season of 2012-2013. The isolated and purified fungi from these seeds were identified as: Alternaria alternata, Penicilliun citrinum and Aspergillus flavus. Occurrence frequencies of the isolated fungi were $75.76,15.16$ and $9.08 \%$, respectively. Toxin production potentials of Alternaria alternata and $P$. citrinum isolates, as estimated by Plug Agar method, were 231.00 and 337.00 $\mu . \mathrm{g} / \mathrm{g}$, respectively., whereas, A.flavus isolate was unable to produce aflatoxins. Sorbic and benzoic acids were proved to be more effective in reducing fungal growth of $A$. alternata and $P$. citrinum than metalaxyl and ridomyl fungicides. $A$. alternata was less sensitive to sorbic acid than benzoic acid. All the tested treatments, at their MICs, significantly reduced growth of $A$. alternata growth and alternariol $(\mathrm{AOH})$ production; however, higher efficiency ratio $(99.860 \%)$ was realized by benzoic acid. Similar inhibition of growth and citrinin (CTN) production was induced by $P$. citrinum. Metalaxyl was less efficient in inhibiting $\mathrm{AOH}$ and CTN than the other tested treatments. Soaking seeds in water significantly raise the efficiency of mycotoxins production in all the tested seed treatments. Moreover, efficiency of benzoic and sorbic acids in reducing $\mathrm{AOH}$ and CTN production was higher during soaking process. Seeds inoculated with the tested pathogens, then treated with sorbic or benzoic acid appeared healthy with normal color, texture and morphology.

Keywords: Mycotoxins inhibition, broadbean seed diseases, Alternaria alternate, Penicillium citrinum, Benzoic acid, Sorbic acid, metalaxyl, Ridomyl.
\end{abstract}

\section{INTRODUCTION}

Broad bean (Vicia faba) is a common staple food in the Egyptian diet. The crop is exposed to infection with many fungal diseases, including those incited by mycotoxin producing fungi, i.e. Alternaria alternata and Penicillium citrinum. Based on estimations of the Food and Agriculture Organization (FAO) of the United Nations, approximately $25 \%$ of the world's food crops are affected by mycotoxin producing fungi and global losses of foodstuffs due to mycotoxins are in the range of 1000 million tons per year.

Alternaria is a common genus with a number of species that can invade crops at the pre- and post-harvest stage and cause considerable losses due to rotting of fruits and vegetables. Some species are fairly specific to particular crops (Broggi et al., 2007). The black mould Alternaria alternata produces a wide diversity of mycotoxins which are of particular health concern. Since no maximum allowable limits are set for Alternaria toxins in food and feed, prevention of Alternaria infestations and mycotoxin spoilage is the only way to avoid health risks (Brzonkalik et al., 2011). A. alternata is probably the most important mycotoxin-producing species which occurs on cereals, sunflower seeds, oilseed rape, olives, various fruits (Whitlow and Hagler, 2013). The principle alternaria mycotoxins that have been shown to occur naturally are tenuazonic acid, alternariol monomethyl ether, alternariol, altenuene, and altertoxin I (Guo et al., 
2004 and Fox and Howlett, 2008). Iso-altenuene and altertoxin II have not been found in crops to date (Barkai-Golan, 2008; Azcarate et al., 2008 and Imazaki et al., 2010). AAL-toxins are produced by $A$. alternata $f$. sp. Lycopersici, a rarely occurring pathotype of $A$. alternata, and are structurally related to fumonisins (Logrieco et al., 2009).

Citrinin is a mycotoxin originally isolated from Penicillium citrinum. It was found to be produced by a variety of other fungi which are found or used in the production of human foods, such as grain, cheese, cake and red pigments (Gordon et al., 2010). Citrinin acts as a nephrotoxin in all species in which it has been tested, but its acute toxicity varies (Bennet and Klich, 2003). Citrinin induces mitochondrial permeability pore opening and inhibits respiration by interfering with complex I of the respiratory chain. Citrinin can permeate through the human skin (Boonen et al., 2012).

The inhibition of fungal growth and mycotoxins production can be achieved by physical, chemical and biological treatments (FAO, 1979). Synthetic chemical fungicides are applied to control fungal growth and mycotoxins production, but they have not been found very effective against mycotoxins. Again their use in plant protection was being de-emphasized due to mammalian toxicity and stimulation of resistance in pathogens stemming from their inappropriate or excessive applications (Tripathi and Dubey, 2004 and Enyiukwu et al., 2014). Heat treatment significantly reduced the concentration of alternariol, alternariol monomethyl ether and tenuazonic acid in $A$. alternata contaminated sunflower flour; however, the heat-treated material produced toxic effects when fed to rats (EFSA, 2011). These drawbacks reported in literature necessitated search for alternatives such as biological control and plant-based pesticides. Weak acids were also used as preservatives in food and feed to prevent fungal spoilage. The most common weak acid preservatives are sorbic acid, benzoic acid and propionic acid (Eeckhout et al., 2013).

Benzoic acid (Codex Alimentarius, 1991 and 2003) and sorbic acid salts are widely applied as food preservatives (Mroueh et al., 2007) and prevention and control of mould growth and mycotoxin production in cereals (Eeckhout et al., 2013). Metalaxyl-M and Ridomyl MZ 72 are systemic fungicides which inhibits protein synthesis in fungi by interference with the synthesis of ribosomal RNA. They are used as foliar spray to control diseases caused by air and soil-borne fungi and to prevent mycotxin production (Singh et al., 2013). According to the available literature, production of Alternaria toxins in broad bean seeds by Alternaria alternata as well as reduction of mycotoxins concentration by treatment broad bean seeds with weak acids such as benzoic or sorbic acid derivatives, according to the available literature, were not studied. There are few or no relevant toxicity data on Alternaria toxins. Alterniol and alterniol monomethyl are genotoxic and phytotoxic (AFSSA, 2009 and EFSA, 2011).

So, the main aim of this study was to isolate and identify the most important mycotoxin producing fungi from edible broad bean seeds, determine their occurrence frequancies, and study the effect of seed treatment with benzoic and sorbic acids on growth and mycotoxin production by these fungi as possible alternative to the application of fungicides. 


\section{MATERIALS AND METHODS}

Samples of broad bean grains were collected from broad bean grain yield cultured in season 2012-2013 and brought to Plant pathology laboratory at Agricultural Botany Department, Faculty of Agriculture, Saba Basha, Alexandria university.

\section{Seed health testing and frequency of the isolated fungi:}

Surface sterilization of 400 seeds was carried out using sodium hypochlorite $70 \%$, sterilized deionized at ratio 1: 4, according to ISTA (1996). After sterilization process, seeds were placed on sterilized $9 \mathrm{~cm}$ diameter filter papers in Petri plates, moistened with $3 \mathrm{ml}$ of distilled water each. Plates were incubated in a growth room at $25 \pm 2{ }^{\circ} \mathrm{C}$ for 8 days under alternative light and dark 12 hours each. Each treatment was replicated thrice (Christensen, 1957). After 8 days of incubation fungal species found growing on the surface of seeds were purified using single spore technique (Hansen, 1926 and Javaid et al., 2006) or hyphal tip technique (Riker and Riker, 1936) and maintained on potato dextrose agar (PDA) slants (Walbeek et al., 1969). Isolates were then identified according to St. Germain and Summerbell (1996), Hoog et al. (2000), Simmons (2007) and Tiwari et al. (2011). Occurrence frequency percentages (PF) were determined according to Samson et al. (1996), Javaid et al. (2006), Mossini and Kemmelmeir (2008) and El-Wakil et al. (2009). The number of colonies growing on each plate were counted for each identified fungus, then their frequency percentages were calculated according to formula, recommended by Pitt and Hocking (1997) :

$\mathrm{PF}=\frac{\text { No.of seeds on which fungus appear }}{\text { Total No.of seeds }}$ X100

\section{Mycotoxin production ability :}

The ability of the isolated fungi for toxin's production was carried out using a qualitative method (Agar plug), recommended by Frisvad and Thrane (1995) with minor modifications according to Mossini and Kemmelmeir (2008).The resulted fluorescence color was observed and registered.

\section{Detection of alternariol and citrinin in fungal solid cultures (confirmatory test) :}

Alterniol (alternariol) and citrinin were quantitatively detected in their solid cultures using HPLC-UV technique according to Azcarat et al. (2008) and Brzonkalik et al. (2011) at The Central Lab, Faculty of Pharmacy, Alexandria University. The obtained citrinin and alternariol standards were brought from Sigma, Aldrich, Cairo, Egypt.

\section{Testing the effect of the tested treatments on fungal radial growth and mycotoxin inhibition:}

The effect of the tested treatments added to PDA culture each on fungal growth were carried out using the colony growth measurement technique (Pitt and Hocking,1997) and mycotoxin inhibition (Table 2). Different concentrations of benzoic and sorbic acids (5, 10, 15 and $25 \mathrm{ppm}$ ) were used and compared its effectiveness with ridomyl and metalaxyl at their recommended dose $(X)$ and, or $(X) \pm 1 / 2 X$; where $X=2.5 \mathrm{~g} / 250 \mathrm{ml}$ water. The MIC values were determined and registered for each treatment in Table (3) according to Krisch et al. (2011). 
5. Estimation of citrinin and alternariol in infected broad bean grains treated with sorbic and benzoic acids:

Infected broad beans $20 \mathrm{gm}$ each was soaked for 12 hours in $100 \mathrm{ml}$ deionized distilled water and deionized distilled water plus treatment at different concentrations as mentioned above. At the end of soaking process time, broad bean seed samples were re-soaked in $100 \mathrm{ml}$ deionized distilled water for 4 hours to get rid of any acid traces, then grains were taken for alternariol and citrinin estimation after accomplishment of sensorial test according to Kütt et al. (2010), Asam et al. (2011) and Brzonkalik et al. (2011).

\section{Sensorial test:}

Aspect and texture of the treated infected seeds were examined after each treatment to test the emergence of any adverse effect of the treatment on the morphology of the treated infected grains in comparison to healthy ones.

\section{RESULTS AND DISCUSSION}

\section{Identification and occurrence frequencies of fungi associated with infected broad bean grains:}

Fungi associated with infected grains were isolated, purified and identified as Alternaria alternata, Penicillium citrinum and Aspergillus flavus. Their occurrence frequencies were shown in Table1. Alternaria alternata showed the highest occurrence frequency $(75.76 \%)$, followed by Penicillium citrinum $(15.16 \%)$, whereas the least frequency $(9.08 \%)$ was detected in Aspergillus flavus.

\section{Mytoxin production potentials:}

Toxins production potentials of the isolated fungi were tested using a qualitative Agar plug method. Colony fluorescence color was yellow for citrinin and bluish green for alternariol. These results were in agreement with Frisvad et al. (2007) and Mossini and Kemmelmeir (2008). No florescence appeared at retention time of aflatoxin standard which indicates the inability of the isolated Aspergillus flavus strain to produce aflatoxins.

Alternariol and citrinin were quantitatively detected using HPLC-UV technique according to Azcarat et al. (2008) and Brzonkalik et al. (2011). Results are presented in table 1 . According to the obtained data, the ability of Penicillium citrinum isolate to produce citrinin (CTN) $(337 \mu \mathrm{g} / \mathrm{g})$ was higher than that of Alternaria alternata isolate to produce alternariol $(\mathrm{AOH})(231 \mu \mathrm{g} / \mathrm{g})$. 
Table (1): Frequency of identified fungi associated with infected broad bean seeds and their ability to produce mycotoxins.

\begin{tabular}{ccccc}
\hline \multirow{2}{*}{$\begin{array}{c}\text { Identified fungal } \\
\text { isolates }\end{array}$} & Frequency $\%$ & \multicolumn{3}{c}{$\begin{array}{c}\text { Mycotoxin production } \\
\text { ability }(\boldsymbol{\mu g} / \mathbf{g})\end{array}$} \\
\cline { 3 - 5 } & & AOH & CIT & AFIB \\
\hline Alternaria alternata & 75.76 & 231.00 & - & - \\
Penicillium citrinum & 15.16 & - & 337.00 & - \\
Aspergillus flavus & 9.08 & - & - & 0.0 \\
\hline Total Frequency & 100 & & & \\
\hline
\end{tabular}

Where: $\mathrm{AOH}=$ Alternariol; $\mathrm{CIT}=$ citrinin; and AFLB $=$ Aflatoxin $\mathrm{B}$.

Results of Table 2 showed the effect of benzoic and sorbic acids at concs. 5, 10, 15 and $25 \mathrm{ppm}$ and metalaxyl and ridomyl fungicides at their recommended dose $(X)$ and, or $(X) \pm 1 / 2 X$ on radial growth and mycotoxin inhibition. Minimum Inhibitory concentration (MIC) values were calculated and presented in table 3.

3. Effect of the tested treatments on fungal radial growth and mycotoxin inhibition :

\section{3- A. Alternaria alternata:}

All the tested treatments have relatively similar efficacy in reducing growth of alternaria, but benzoic acid was rather best, it realized the highest efficacy ratio $(99.86 \%)$. These findings were, relatively, in agreement with those of Erich (1980) and Combina et al. (1999), who reported that levels above $10 \mathrm{mg} / \mathrm{kg}$ of sodium benzoate and potassium sorbate produced a total inhibition of fungal development and toxin biosynthesis. Our results were also in line with those reported by Embaby et al. (2013), Javaid et al. (2006), and Sitara and Hasan (2011), who concluded that ridomyl was effective against Alternaria alternata at concentrations 0.15 and $0.25 \%$.

Increase in treatment's concentration in the present study was not necessarily followed by an increase in the fungal growth inhibition. However, the relationship between the fungicide's concentration and fungal growth inhibition was directly proportional. Benzoic acid (25 ppm) and ridomyl $11 / 2 X(X=2.5 \mathrm{~g} /$ $250 \mathrm{ml}$ water) completely inhibited $\mathrm{AOH}$ production; however, fungal behaviour in responding against benzoic acid and ridomyl was differed. Our results are relatively in agreement with those of Uraih and Chipley (1976) and Uraih and Offonery (1981), who found that benzoic acid completely inhibited Aspergillus flavus growth and aflatoxin production at $10 \mathrm{mg} / \mathrm{g}$.

Inhibition of Alternaria growth throughout our work was in line with that reported by Sofos and Busta (1983 and 1993). They concluded that the antimicrobial action of sorbic acid is due to its inhibitory influence on various enzymes in the microbial cell. 


\section{3- B. Penicillium citrinum}

All the tested concentrations of benzoic and sorbic acids and ridomyl at concentration $11 / 2 X$ (i.e., $1.25 \mathrm{~g} / 250 \mathrm{ml}$ water) were similar in their efficiency in reducing fungal growth. The least Penicillium growth reduction rates were attained by Metalaxyl. These findings coincided with those of Cohen (1981), who found that metalaxyl enhanced the Penicillium growth. This contradiction may due to variations in the tested isolates of Penicillium citrinum. Highest growth reduction rates were observed in ridomyl treatments. This was in harmony with those of Javaid et al. (2006), who found that metalaxyl plus mancozeb (ridomyl) was the most effective fungicide in reducing fungal growth in Penicillium.

\section{3- C. MIC of the tested treatments}

Data in Table (3) indicated that metalaxyl at the tested concentrations failed in reaching MIC >90\% growth inhibition. Fungal growth inhibition in general was more sensitive to treatments than mycotoxin inhibition. Both of the tested fungi have the similar behavior toward both of the two tested weak acids; however, they differed in their response to the effect of the tested fungicides. Penicillium citrinum was more tolerant to both fungicides than Alternaria alternata. Similar results were obtained by Abd-El Ghany and Tayel (2009), who reported that Penicillium citrinum was more tolerant to metalaxyl at high concentrations (400-800 ppm).

\section{Effect of water soaking process on mycotoxins production (Sensorial test):}

Data in Table (4) indicated that soaking process without the tested treatments did not significantly affect mycotoxin inhibition. Our results may appear incompatible and ambiguous with other findings concerning the washing grains process with tap water under pressure which significantly reduces the mycotoxin content in mould-contaminated grains by reducing fungal inocula (Wilson et al., 2004; Fandohan etal., 2005, and Jouany, 2007).This contradiction may due to differences in soaking process. Throughout the present experiment water soaking of infected seeds contaminated with mycotoxin was carried out without any water pressure. Washing infected seeds under water pressure may lead to the the removal of the fungal spores and consequently reduced the produced mycotoxin.

The efficiency of benzoic and sorbic acids in reducing $\mathrm{AOH}$ increased during soaking process. All the tested concs., except for $25 \mathrm{ppm}$ treatment gave higher reduction rates during soaking process. Our results are partially in agreement with Darmen (2013). On the other hand, during soaking process, all the tested concentrations of both acids significantally inhibited CTN production reduction rates during soaking process. Our results are partially in agreement with Darmen (2013). On the other hand, during soaking process, all the tested concentrations of both acids significantally inhibited CTN production. 
Table (2): Effect of the tested weak acids and fungicides on fungal growth and mycotoxins production.

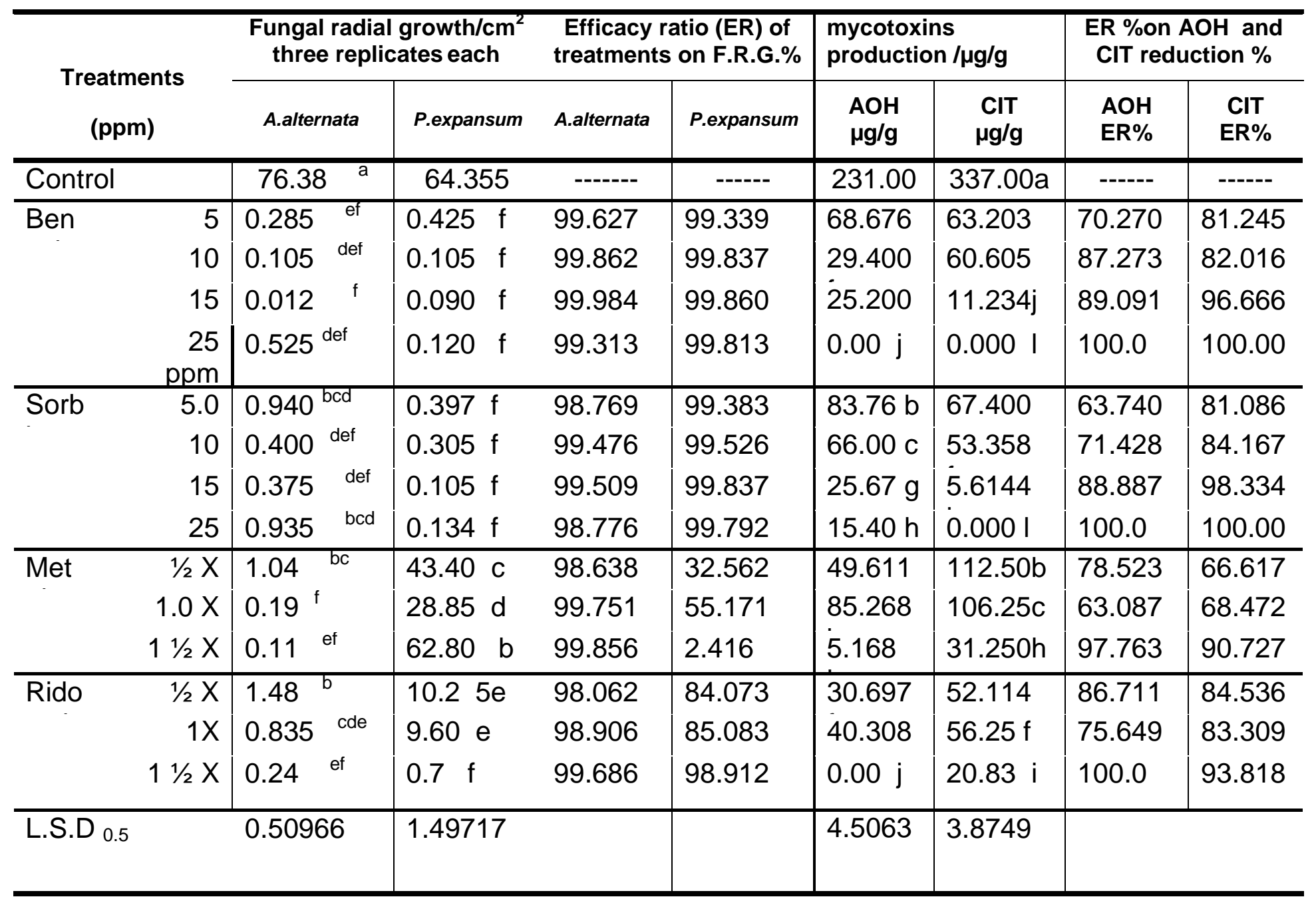


Table (3): Minimum inhibitory concentration (MIC) of the tested treatments

\begin{tabular}{lc|c|c|c}
\hline Treatments & \multicolumn{4}{c}{ MIC* $^{*}$} \\
\cline { 2 - 5 } & A.alternata & P.Citrinum & Alternariol & Citrinin \\
\hline Benzoic acid & $5 \mathrm{ppm}$ & $5 \mathrm{ppm}$ & $25 \mathrm{ppm}$ & $15 \mathrm{ppm}$ \\
Sorbic acid & $5 \mathrm{ppm}$ & $5 \mathrm{ppm}$ & $25 \mathrm{ppm}$ & $15 \mathrm{ppm}$ \\
Metalaxyl & $1 / 2 \mathrm{X}^{\circ}$ & $(--)$ & $11 / 2 \mathrm{X}$ & $11 / 2 \mathrm{X}$ \\
Ridomyl & $1 / 2 \mathrm{X}$ & $11 / 2 \mathrm{X}$ & $1 \frac{1}{2} \mathrm{X}$ & $11 \frac{1}{2} \mathrm{X}$ \\
\hline
\end{tabular}

Where: $\left.*^{*}\right)$ : MIC is the lowest concentration where $>90 \%$ growth inhibition is determined (Krisch et al., 2011); ${ }^{\circ} \mathrm{X}: 2.5 \mathrm{~g} / 250 \mathrm{ml}$ water; and (--): i.e., undectable value.

Generally, our findings fairly consistent with those of Ragab et al. (2007), who reported that modifying the traditional process of 'balila' preparation by using $\mathrm{Na}_{2} \mathrm{CO}_{3}$ solution during water soaking process may be useful to reduce the risk of mycotoxin exposure via 'balila'. Soaking process ameliorate the efficiency of the tested weak acids.

The appearance, the texture and the overall shape of the treated infected seeds were similar to those of the natural seeds. However, water soaked seeds appeared steel blackish, may be due to changes in the chemical structure of water during soaking process which allow seeds to get rid of pigment. KoffiNevry et al. (2013) found that water soaking reduce some nutritive components involved in the activation of enzymes responsible for mycotoxin production. These findings were explained by Calvo et al. (2002), who found that in Alternaria alternata, melanin pigment deposition is also involved in spore development. Disruption of the A. alternata melanin biosynthetic gene brm2 dramatically decreases melanin production in this fungus (Kumura and Tsuge, 1993, and Kawamoura et al.,1999). In our study, this disruption of melanin biosynthesis may occur as a result of denaturation of gene brm2 encoding enzymes responsible of melanin production enhanced by treatment with benzoic and sorbic acids during water soaking. This finding was highly in agreement of those of Shad et al. (2012), who reported that sorbic acid works on the active sites of enzymes and interacted with substrate to inactivate enzymes. This enzymes inactivation was positively proportional to sorbic acid concentration.

Inhibition of alternariol and citrinin by benzoic and sorbic acids throughout the present study may due to the inhibition of the accumulation of Acetyl CoA, the precursor of mycotoxins biosynthesis (Uraih et al., 1977; Hajjaj et al., 1999; Scott, 2001; Elizabeth, 2008 and Saha et al., 2012)) and preventing 
the condensation of acetyl CoA with malonyl (Eckhout et al., 2013), which finally resulted in complete blocking of mycotoxins biosynthesis.

Table (4): Effect of seed re-water soaking process on mycotoxins production throughout the tested treatments

\begin{tabular}{lcccc}
\hline \multicolumn{1}{c}{ Treatments } & $\begin{array}{c}\text { Av. of AOH } \\
\mu \text { g/kg }\end{array}$ & $\begin{array}{c}\text { E.R.\% } \\
\text { of } \\
\text { Soak..P }\end{array}$ & $\begin{array}{c}\text { Av. of CTN } \\
\mu \mathbf{g} / \mathbf{k g}\end{array}$ & $\begin{array}{c}\text { E.R. \%of } \\
\text { Soak.P }\end{array}$ \\
\hline Soak. control & $229.656 \mathrm{a}$ & - & $334.104 \mathrm{a}$ & 0.4458 \\
Non Soak control & $230.786 \mathrm{a}$ & 0.4896 & $335.600 \mathrm{a}$ & -------- \\
Soak + Benzoic 5ppm & $16.587 \mathrm{~cd}$ & 92.777 & $49.579 \mathrm{c}$ & 85.161 \\
Soak + Benzoic 10ppm & $14.925 \mathrm{cde}$ & 93.501 & $24.789 \mathrm{~d}$ & 92.570 \\
Soak + Benzoic 15ppm & $10.837 \mathrm{de}$ & 95.281 & $0.000 \mathrm{e}$ & 100.0 \\
Soak + Benzoic 25ppm & $7.9420 \mathrm{e}$ & 96.542 & $0.000 \mathrm{e}$ & 100.0 \\
Soak + Sorbic 5ppm & $23.794 \mathrm{~b}$ & 89.639 & $67.635 \mathrm{~b}$ & 79.756 \\
Soak + Sorbic 10ppm & $19.589 \mathrm{bc}$ & 91.470 & $27.805 \mathrm{~d}$ & 91.678 \\
Soak + Sorbic 15ppm & $16.455 \mathrm{~cd}$ & 92.835 & $0.000 \mathrm{e}$ & 100.0 \\
Soak + Sorbic 25ppm & $13.123 \mathrm{cde}$ & 94.286 & $0.000 \mathrm{e}$ & 100.0 \\
\hline
\end{tabular}

Where: SOAK = saoking broad bean seeds in distilled water; ER\% of Soak.P $=$ Efficacy ratio of soaking process $=$ (soaked seeds - soaked seeds + treatment/soaked seeds) $\times 100 ; \mathrm{AOH}=$ Alternariol; $\mathrm{CTN}=$ Citrinin; and ${ }^{*}=($ Non soaked seeds- soaked seeds/ Non soaked seeds) $x 100$.

\section{CONCLUSION}

According to the obtained results, we can remarked that benzoic and sorbic acids are highly effective in inhibiting $A$. alternata, $P$. citrinum growth and alternariol and citrinin production by these fungi.

The problem of non-safe use of these food preservatives do not exist in our study because the tested concentrations of these acids were less than recommended doses (Codex Alimentarius, 1991). In addition to that broad bean seeds greatly differed in structure, compared with acidic foods and beverages. Furthermore, For humans, the World Health Organization's International Programme on Chemical Safety (IPCS, 1999\&2004, and JECFA, 2005) 
suggests a provisional tolerable intake for infants would be $5 \mathrm{mg} / \mathrm{kg}$ body weight per day for benzoic acid and its salts (Takao and Takeda, 2003 and WHO, 2009).

There are currently no statutory or guideline limits set for Alternaria mycotoxins because surveys to date have shown that their natural occurrence in foods is very low and the possibility for human exposure is very limited. The need for regulation is kept under review as new information becomes available.

The re-water soaking process proves that benzoic and sorbic acids are not acting as fungistatic but fungicides. So, we can considered these tested weak acids as fungicides alternatives to metalaxyl and ridomyl synthetic fungicides.

\section{REFERENCES}

Abd-EL-Ghany, T. M. and A. A., Tayel. 2009. Efficacy of certain Agrochemicals application at field raes on soil fungi and their ultrstructures. Research J. of Agriculture and Biological Sciences, 5(2):150-160.

AFSSA (Agence française de sécurité sanitaire des aliments). 2009. Evaluation des risques lies à la presence de mycotoxins dans les chaînes alimentaires humaine et animale. Rapport final, mars 2009, 308 pp.

Asam, A., K. Konitzer and M. Rychlik. 2011. Precise determination of the Alternaria mycotoxins alternariol and alternariol monomethyl ether in cereal, fruit and vegetable products using stable isotope dilution assays. Mycotox. Res., 27: 23-28.

Azcarate, M. P., A. Patriarca, L. Terminiello and P. V. Fernández. 2008. Alternaria toxins in wheat during the 2004 to 2005 Argentinean harvest. J. Food Prot., 71: 1262-1265.

Barkai-Golan, R. 2008. Mycotoxins in fruits and vegetables. Barkai-Golan, R., and Paster, N., editor. Elsevier, San Diego; 2008. Alternaria mycotoxins; pp. 86-89 and 185-199.

Bennett, J. W. and M. Klich. 2003. Mycotoxins. Clin Microbiol Rev. 16: 497516.

Boonen, J., S. V. Malysheva, L. Taevernier, D. J. Di Mavungu, S. De Saeger and De B. Spiegeleer. 2012. Human skin penetration of selected model mycotoxins. Toxicology, 30: 2132.doi:10.1016/j.tox.2012.06.012.

Broggi, L. E., H. H. L. González and S. L. R. Y. Pacin. 2007. Alternaria alternata prevalence in cereal grains and soybean seeds from Entre Rios, Argentina, Reviberoam, Micol., 24: 47-51.

Brzonkalik, K., T. Herrling, C. Syldatk and A. Neumann. 2011. Process development for the elucidation of mycotoxin formation in Alternaria alternata. AMB Express. 2011,pp 1: 27. doi: 10.1186/2191-0855-1-27.

Calvo, A. M., R. A. Wilson, J. Woo Bok and N. P. Keller. 2002. Relationship between secondary metabolism and fungal development. Microbiol. Mol. Biol. Rev., 66(3): 447-459.

Christensen, C. M. 1957. Deterioration of stored grains by fungi. Botan. Rev., 23(2): 108-134. 
Codex alimentarius commission. 1991. Joint FAO/WHO Food Standards Programme Codex alimentarius, commission nineteenth session, Rome, 1-10 July.

Codex Committee on Food Additives and Contaminants, Thirty-fourth Session. 2003. Codex Alimentarius Commission/RCP, 51-2003.

Cohen. E. 1981. Metalaxyl for postharvest control of of brown rot of citrus fruit. Plant Disease, 65: 672-675.

Combina, M., A. M. Dalcero and S. Chulze. 1999. Effects of food preservatives on Alternaria alternata growth and tenuazonic acid production. Food Addit. Contam., 16(10):433-437.

Darman, R. D. 2013. Sustainability and effectiveness of artisanal approach to control mycotoxins associated with sorghum grains and sorghum based food in Sahelian Zone of Cameroon. Intech. Chapter 6: 1-16. http://dx.doi.org/10.5772/54789.

Eeckhout, M., S. Ladschoot, N. Deshuyffeleer, S. De Laethauwer and G. Haesaert. 2013. Guidelines for prevention and control of mould growth and mycotoxin production in cereals. Mycohunt, pp 37.

EFSA (European Food Safety Authority), EFSA Panel on contaminants in the food Chain. 2011. Scientific opinion on the risks for animal and public health related to the presence of Alternaria toxins in feed and food.. EFSA Journal, 9(10): 2407.

El-Wakil, M. A., I. M. El Refai, O. A. Awadalla, M. A. El Metwally and M. S. Mohammed. 2009. Seed-borne pathogens of faba bean in Egypt: detection and pathogenicity. J. of Plant Pathology, 8(3): 90-97.

Elizabeth, M. H. 2008. Exploration of structure and function in biomolecules through solid-state NMR and computational methods. Book, google.com.eg. C.F., phD in the subject of physics. Pp. 119-125. Utah University., U.S.A.

Embaby, E. S. M., M. Hazaa, L. F. Hagag, T. E. S. Ibrahim and F. S. Abd El-Azem. 2013. Decay of some citrus fruit quality caused by fungi and their control: II- Control of Alternaria rot or core rot decay by using some alternative fungicides. Journal of Applied Sciences Research, 9(11): 5671-5678.

Enyiukwu, D. N., A. N. Awurum and J. A. Nwaneri. 2014. Mycotoxins in stored agricultural products: Implications to food safety and health and prospects of plant-derived pesticides as novel approach to their management. Greener Journal of Microbiology and Antimicrobials, 2(3): 32- 48.

Erich, L. 1980. Sorbates in antimocrobial food additives: characteristics, uses, effects. Translated from German by Grant F. Edwards, SpringerVerlag, Berlin, Heidelberg, New York. pp 257.

Fandohan, P., D. Zoumenou, D. J. Hounhouigan, W. F. O. Marasas, M. J. Wingfield and Hell, K. 2005. Fate of aflatoxins and fumonisins during the processing of maize into food products in Benin. Int. J. Food Microbiol., 98: 249-259.

FAO. 2014.(http://www.fao.org/food/food-safety-quality/home-page/ar/).

FAO.1979. Recommended practice for prevention of mycotoxins in food, feed and their products, Rome, 1979, 4-36 
Fox, E. M, and B. J. Howlett,. 2008. Secondary metabolism: Regulation and role in fungal biology. Curr. Opin. Microbiol., 11:481-487.

Frisvad, J. C. and C. A. Thrane. 1995. Mycotoxins production by foodborne fungi. In Samson. R.A., Hoekstra, E. S., Frisvad J. C. and Filtenborg, O. (ed.), Introduction to food borne fungi, 4th ed., pp.251-260.

Frisvad, J. C., T. O. Larsen, R. DeVries, M. Meijer, J. Houbraken, F. J. Cabanes, K. Ehrlich and R. A. Samson. 2007. Secondary metabolites profiling, growth profiles and other tools for species recognition and important Aspergillus mycotoxins, SIM, 59: 31-37.

Gordon, R. Y., T. Cooperman, W. Obermeyer and D. J. Becker. 2010. "Marked variability of monacolin levels in commercial red yeast rice products: buyer beware. Archives of Internal Medicine, 170(19): 17221727. doi:10.1001/archinternmed.2010.382. PMID 20975018.

Guo, L. D., L. Xu, W. Zheng, K. D. Hand Hyde. 2004. Genetic variation of Alternaria alternata, an endophytic fungus isolated from Pinus tabulaeformis as determined by random amplified microsatellites (RAMS). Fungal Divers, 16:53-65.

Hajjaj, H., A. Klaebe, M. O. Loret, G. Goma, P. J. Blanc and J. Francois. 1999. Biosynthetic pathway of citrinin in the filamentous fungus Monascus ruberas revealed by $\mathrm{C}^{13}$ nuclear magnanetic resonance.Appl. Environ. Microbiol., 65(1):311-314.

Hansen, H. N. 1926. A simple method of obtaining single spores culture. Science, 64:384.

Hoog, G. S., J. Guarro, J. Gene and M. J. Figueras. 2000. Atlas of clinical fungi, 2nd ed., vol. 1. Centraal bureau voor Schimmelcultures, Utrecht, The Netherlands.

Imazaki, A., A. Tanaka, Y. Haimoto, M. Yamamoto and K. Akimitsu. 2010. Contribution of peroxisomes to secondary metabolism and pathogenicity in the fungal plant pathogen Alternaria alternata. Eukaryot Cell, 9: 682-694.

International Programme on Chemical Safety (IPCS), WHO. 1999. Evaluation of national assessments of intake of benzoates. WHO Food Additives Series No. 42. Geneva: Available from URL. (http://www.inchem.org/documents/jecfa/jecmono/v042je22.htm).

International Programme on Chemical Safety. 2004. Project on the harmonization of approaches to the assessment of risk from exposure to chemicals.

ISTA (International Seed Testing Association). 1996. International rules for seed testing. Seed Sci. Technol., 24:1-335.

Javaid, A., A. Ashraf, N. Akhtar, M. Hanif and M. A. Farooq. 2006. Efficacy of some fungicides against seed-borne mycoflora of wheat. Mycopath., 4(1): 45-49

JECFA. 2005. The Joint FAO/WHO Expert Committee on Food Additives. 2005. summary of evaluations performed by jecfa -benzoic acid. Rome, FAO, Available from URL. http://www.inchem.org/documents/jecfa/jeceval/jec_184.htm

Jouany. J. P. 2007. Methods for preventing, decontaminating and minimizing the toxicity of mycotoxins in feeds. Animal Feed Science and Technology, 137: 342-362. 
Kawamura, C., T. Tsujimoto and T. Tsuge. 1999. Targeted disruption of a melanin biosynthesis gene affects conidial development and UV tolerance in the Japanese pear pathotype of Alternaria alternata. Mol. Plant-Microbe Interact., 12: 59-63. [PubMed].

Koffi-Nevry, R., M. Koussémon, W. A. M. Alloue-Boraud and K. Kouassi. 2013. Assessing the microbiological level and the incidence of watersoaking on the proximate composition of two cultivars of cowpea (Vignaunguiculata L.) grains grown in Côte d'Ivoire. British Microbiology Research Journal, 3(3): 206-217.

Krisch. J, R. Tserennadmid and C. VágvÖlgyi. 2011. Essential oils against yeasts and moulds causing food spoilage c.f. Science against microbial pathogens: communicating current research and technological advances. A. Méndez-Vilas. (Ed.) CFormatex 2011, 1135-1142.

Kumura, N. and T. Tsuge. 1993. Gene cluster involved in melanin biosynthesis of the filamentous fungus Alternaria alternata. J. Bacteriol., 175: 4427-4435.

Kütt, M. L., H. Lõiveke and R. Tanner. 2010. Detection of alternariol in Estonian grain samples. Agronomy Research., 8 (II): 317-322.

Logrieco, A., A. Moretti and M. Solfrizzo. 2009. Alternaria toxins and plant diseases: an overview of origin, occurrence and risks. World Mycotoxin Journal, 2:129-140.

Mossini, S. A. G. and C. Kemmelmeir. 2008. Inhibition of citrinin production in Penicillium citrinum cultures by neem [Azadirachta indica A.Juss] (Meliaceae). Int.J. Mol. Sci., 9(9):1676-1684.

Mroueh, M., D. Issa, J. Khawand, B. Haraty, A. Malek, Z. Kassaify, and I. Toufeili. 2007. Levels of benzoic and sorbic acid preservatives in commercially produced yoghurt in Lebanon. Journal of Food, Agriculture \& Environment, 6(1): 62-66.

Pitt, J. I. and A. D. Hocking. 1997. Fungi and food spoilage. New York, Blackie Academic Professional, pp 593.

Ragab, W. S, S. Drusch, F. Schnieder and M. Beyer. 2007. Fate of deoxynivalenol in contaminated wheat grain during preparation of Egyptian 'balila'. Int. J. Food Sci. Nutr., 58(3):169-77.

Riker, A. J. and R. S. Riker. 1936. Introduction to research on plant diseases. John. S. Swift Co. Inc. St. Lovis, Chicago, NewYork.

Saha, D., Fetzner, R., Burkhardt, B., Podlech, J., Metzler, M., Dang, H., Lawrence, C.1, and Fischer, R. (2012). Identification of a polyketide synthase required for alternariol $(\mathrm{AOH})$ and alternariol-9-methyl ether (AME) formation in Alternaria alternata. Plos One 7. Open Access Peer-Reviewed. Research Article. doi:10.1371/journal.pone.0040564.

Samson, R. A., E. S. Hoekstra, J. C. Frisvad and O. Filtenborg. 1996. Introduction to food-borne fungi (6th edition), central bureau voor schimmel cultures, Baarn, The Netherlands.

Scott, P. M. 2001. Analysis of agricultural commodities and foods For Alternaria mycotoxins. J. of AOAC International, 84: 1809-1817.

Shad, M. A., Z. I. Zafar, H. Nawaz and F. Anwar. 2012. Effect of sorbic acid and some other food preservatives on human serum cholinesterase activity. African J. of Biotechnol., 11(51): 11280-11286. 
Simmons E.G. 2007. Alternaria: An identification manual. Centraal bureau Voor Schimmelcultures, Utrecht, $775 \mathrm{pp}$.

Singh, S. K., V. Gupta, D. John, V. Padha and V. K. Razdan. 2013. Evaluation of fungicides and biological control agents for integrated management of spot blotch of wheat. J. Mycol. Plant Pathol., 43(1).

Sitara, U. and N. Hasan. 2011. Studies on the efficacy of chemical and nonchemical treatments to control mycoflora associated with chilli seed Pak. J. Bot., 43(1): 95-110.

Sofos, J. N. and F. F. Busta. 1983. Branen and Davidson, eds. Sorbates: Antimicrobials in foods. Previously published in Vineyard \& Vintage View, Mountain Grove, MO.

Sofos, J. N. and F. F. Busta. 1993. Sorbic acid and sorbates. In "Antimicrobials in Foods," ed. P.M. Davidson and A.L. Branen, 2nd ed., pp. 49-94. Marcel Dekker, N.Y.

St. Germain, G. and R. Summerbell. 1996. Identifying filamentous fungi- A Clinical laboratory handbook, 1st ed. Star Publishing Company, Belmont, California.

Takao, M. and K. Takeda. 2003. Benzoic Acid and derivatives" in Ullmann's Encyclopedia of Industrial Chemistry 2002, Wiley-VCH, Weinheim. Clin Microbiol Rev., 16(3): 497-516.

Tiwari, K. L., S. K. Jadhav and A. Kumar. 2011. Morphological and molecular study of different Penicillium species. Middle-East Journal of Scientific Research, 7(2): 203-210.

Tripathi, P. and N. Dubey. 2004. Exploitation of natural products as alternative strategy to control postharvest fungal rotting of fruits and vegetables. Postharvest biology and Technology, 32(3): 235-245.

Uraih, N. and J.R. Chipley. 1976. Effects of various acids and salts on growth and aflatoxin production by Aspergillus flavus NRRL 3145. Microbios., 17(67):519.

Uraih, N. and S. Offonry . 1981. Inhibition of aflatoxin production in groundnut with benzoic acid derivatives and possible toxic effect of their aromatic residues. Microbios., 31(124):93-102.

Uraih, N., T. R. Cassity and J. R. Chipley. 1977. Partial characterization of the mode of action of benzoic acid on aflatoxin biosynthesis. Can. J. of Microbiol., 23(11):1508-4.

Walbeek, V., T. Clademenous and F. S. Thatcher. 1969. Influence of refrigeration on Aflatoxins production by strains of Aspergillus flavus. Can. J. Microbiol., T.XV: 629-632.

Whitlow, L. W. and W. M. Hagler. 2013. Mycotoxin contamination of feedstuffs - an additional stress factor for Diary cattle, $32 \mathrm{pp}$. www.cals.ncsu.edu/.../myco 1.pd... Retrieved November 10, 2013. See

more at:http://gjournals.org/GJMA/Publication/2014/July/HTML/0521014241 \%20Enyiukwu\%20et\%20al.htm\#sthash.oMgrbJGB.dpuf.

WHO (World Health Organization). 2009. Principles and methods for the risk assessment of chemicals in food, international programme on chemical safety, environmental health criteria, pp 240. Chapter (6): Dietary exposure assessment Of chemicals in food. Available from http://www.who.int/ipcs/food/principles/en/index1.html. 
Wilson, S. C., T. L. Brasel, C. G. Carriker, G. D. Fortenberry, M. R. Fogle, J. M. Martin, C. Wu, L. A. Andriychuk, E. Karunasena and D. C. Straus. 2004. An investigation into techniques for cleaning mouldcontaminated home contents. J. Occup. Environ. Hygiene, 1: 442447.

\section{الملخص العربى \\ تأثثر أحماض البنزويك والسوربيك على تثبيط السموم الفطرية فى بذور الفول المعدة للأكل}

\section{نسرين يوسف², إبراهيم السمرة" وأحمد عبد البارى1 1}

'كلية الزراعة, سابا باشا, جامعة الإسكندرية؛ 2 مركز البحوث الزراعية, وزارة الزراعة المصرية

إستهدفت الدراسة الحالية التعرف على الفطريات المصاحبة للبذور وتتقيتها وتعريفها, وإختبارمدى قدرة

السلالات الفطرية المعزولة على إنتاج السموم الفطرية وتعريف كمى ونوعى لهذه السموم, وإستحداث أسلوب عملى ولى بسيط لمعالجة البذور قبل الطهى والأكل للتخلص وتقليل محتوى البذور من السموم الفطرية وذللك باستخدام بدائل

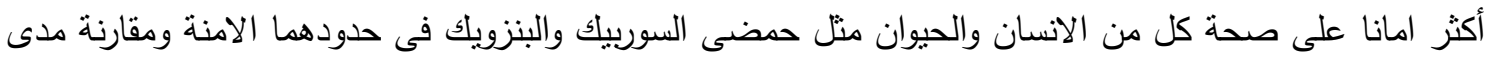
كفاءة المبيدات الفطرية والاحماض المذكورة على النمو الفطرى وتثبيط انتاج السموم الفطرية.

ولقد توصل البحث إلى عزل سـالات من فطر ألترناريا ألترناتا, بنيسيليوم سنريكتام وأسبرجلس فلافس بنسـب تواجد بلغـت 15,76\%, 15,16\% و 9,08\%, على التـوالى. ولقد دلت الإختبـارات على قدرة سـلالة الألترناريـا على إفراز الألترناريول بنسبة

337.00 pg/g

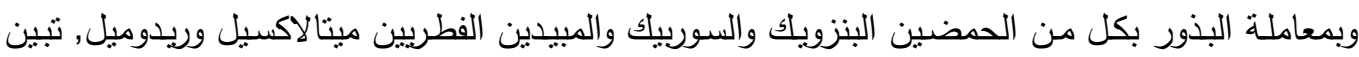
تفوق فاعليـة الأحمـاض المختبرة على المبيدات الفطريـة فى قدرتها على خفض النــو الفطرى للفطرين محل الاختبار • وكان الفطر التزناريا الترناتا اقل حساسية لحمض السوربيك بالمقارنة بحمض البينزويك. وتقاربت نتائج تثبيط النمو الفطر فى جميع معاملات الألترنريـا مـع تفوق طفيف لحمض البنزويك. كم كان جميع معاملات

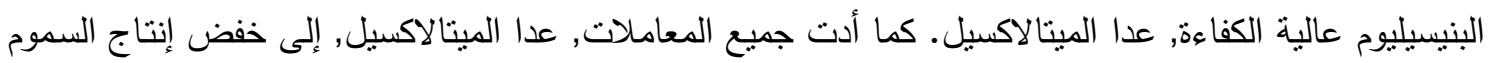
المختبرة, بل تعدى الأمر إلى إحداث تثبيط تام لإنتاجها. أدت عملية النقع للبذور غير المعاملة بالماء لمدة 12 ساعة إلى تأثثرات غير جوهرية على الدهات المتوى من

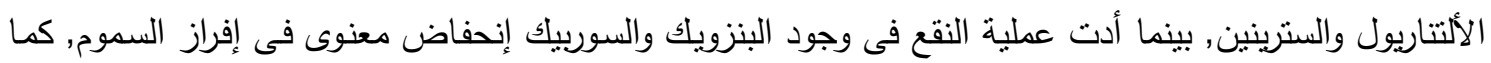

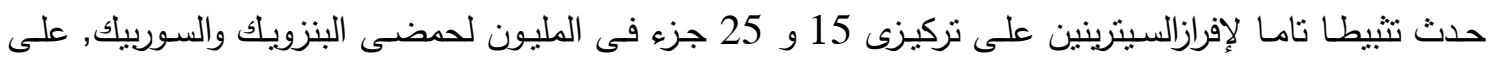

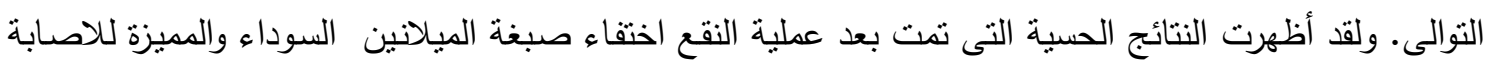

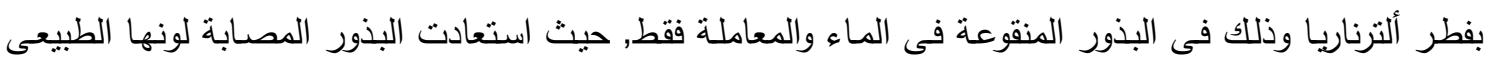
واصبحت البذور المصابة تمانل البذور السليمة فى شكلها الظاهرى من حيث لونها ونسيج البذورنفسها. 
